Iuliia Magdych ${ }^{1}$

\title{
FEATURES OF POLITICAL MANIPULATION OF THE VALUE-WORLDVIEW COMPONENT OF PUBLIC CONSCIOUSNESS
}

Keywords: political governance, political manipulation, political culture, political behavior, political consciousness, values.

\begin{abstract}
Today, the problem of political governance is one of the most important. There is an urgent need to create standards and institutions that would be effective and adequate to peculiarities of the contemporary society. One of the forms of socio-political governance is political manipulation of public consciousness. Modernization of the political system of society causes corresponding changes in the processes of management and manipulation. The influence on political consciousness and behavior is different at the traditional, modern and so-called postmodern stages of social development. The genesis of political manipulation of worldview values is the subject of this study. In the structure of political consciousness, which is a component of political culture, the value-worldview component is one of the most important. Values forms a motivational basis of political behavior. It is argued that values change in the predicted direction, and political manipulation could affect the value orientations of public consciousness. Analysis of the state of scientific development of the problem of political manipulation shows that the value-worldview component as an important component of political consciousness is poorly studied. The study of the peculiarities of political manipulation of the value component of political consciousness in the framework of this article is important, because the corresponding cultural dynamics affects the functioning of the political system.
\end{abstract}

Thus, the relevance and practical significance of this study is that it analyzes the main characteristics of political manipulation of the value-

1 Postgraduate Student at the Department of Public Administration, Taras Shevchenko National University of Kyiv, firenze2016@ukr.net. ORCID: 0000-0002-0638-1591. 
worldview component of public consciousness in the historical context. Both formal and semantic characteristics of political manipulation of public consciousness could change, changes in the value orientations of society play a crucial role in the emergence and development of democratic political institutions. At the present stage of development, pluralistic values of self-expression predominate in the structure of public consciousness, and the security priorities of post-industrial development fundamentally differ from pre-industrial and industrial ones. However, the variability of political values and meanings in the postmodern will contribute to the further formal improvement of the technologies of political manipulation. At the present stage in the processes of political manipulation there is an impact on both emotional component of political consciousness and cognitive one (accordingly individual political behavior is corrected, and mass one as well). Freedom as a political leitmotif of the modern paradigm and security as a fundamental value of traditional society, have a complex relationship at the present stage, their optimal combination is one of the priorities of public policy and public administration.

\section{INTRODUCTION}

In this article I intend to describe the historical stages of the political manipulation genesis. The aim of the article is to highlight the characteristics of political manipulation of the value-worldview component of public consciousness. Using obtained data, I would like to characterize the main features of the process of political manipulation of the valueworldview component of public consciousness at the traditional, modern and postmodern stages of society development.

Theoretical and methodological basis for the analysis of the peculiarities of political manipulation of the value-worldview component of social consciousness are both general-scientific and special-scientific methods of cognition. Systemic and structural-functional methods made it possible to clarify the place and role of political manipulation in the political process and the political system. The genesis of manipulating the value 
component of political consciousness was studied using the historical method. The comparative method allowed to determine the characteristics of political manipulation of values and worldviews at each stage of sociopolitical development. The main empirical basis was the results of the sociological research project "World Values Survey" (WVS, 2020).

\section{TRENDS IN CONTEMPORARY THEORETICAL RESEARCH ON POLITICAL MANIPULATION}

The analysis of foreign and domestic studies in the field of sociopolitical management allows to represent the main directions and trends in modern theoretical research on political manipulation. It should be noted that the research is mostly interdisciplinary in nature, and the concept of "political manipulation» is not sufficiently inscribed in the system of political science categories. With the help of systemic and structural-functional approaches, manipulation can be attributed to both the communicative subsystem of the political system and the functional one. In the political system of society, manipulation is one of the means of communicative retransmission of values and ensuring systemic stability. An example of work that can be used in an interdisciplinary approach is a fundamental study by psychologist D. Kahneman (2017) «Thinking, Fast and Slow», the main provisions of which are applied in conceptual studies on the issue of political manipulation. In general, it could be noted that there are many scientific and popular science developments devoted to the political manipulation (Adzhemohlu, Robinson, 2020; Coons, Weber, 2014; Levitin, 2017; Maklyuen, 2014; Moroz, 2020; Nyst, 2018; Pomerantsev, 2020). However, the problem of political manipulation of the value component of public consciousness, considering both historical and contemporary aspects, is studied insufficiently.

To study the genesis of political manipulation, I single out the main historical stages of its development: premodern (or traditional), modern and postmodern (corresponding to agrarian, industrial, and post-industrial societies) ones. Each of these periods is characterized by corresponding specific features. For example, in the traditional paradigm, politics is 
the art of governing; in modern period politics acquires a technological and partnership nature, which is the result of a social contract; in postmodern era politics is perceived as a game and «the art of the possible.» Manipulation exists at all stages of socio-political development, but historically significantly changes its formal and substantive characteristics. If at the traditional stage political manipulation is not the main form of socio-political governance, then with social modernization it becomes massive and systematic, being one of the main forms of management of political consciousness and behavior. At the present stage there is a further technological development of political manipulation forms. The corresponding transformation of political structures has been studied in numerous foreign and domestic sources. The main characteristics of traditional society are traditionalism, collectivism, ritualism, holism, mythologizing, sacralization, hierarchy, symbolism, etc. Modernization is the development of society economically - through industrialization, politically - through bureaucratization. It also deals with transition from traditional value systems to new, modern ones.

In the political context, modernization can be considered as a transition from a «closed» to an «open society» with the prevalence in the latter of democratic principles of political organization. Historically, liberal ideology is inscribed in the logical scheme of modernism. Freedom becomes the greatest value of modern society; the political concepts of modern liberalism determined the emergence of appropriate state and political institutions. Modernization changes also affected power structures: from religious power to rational-bureaucratic one, from hierarchical power to decentralized one, from traditional legitimacy to rational-legal power. Thus, modernism is characterized by the following main features: rationality, scientificity, bureaucracy, conventionality, secularism, etc. At the same time, the current socio-political situation is characterized by significant manufacturability, hybridization, uncertainty, and so on. To clarify the genesis of political manipulation, the historical method is used, to determine its features at each of the selected stages a comparative one.

Value orientations determine both political consciousness and political behavior. Values play a fundamental role in the functioning of political 
culture. Political manipulation is one of the means by which the support of the authoritarian distribution of values in society is achieved.

The values of modern society are different from the values of traditional society. The results presented in the work by R. Inglehart and Ch. Welzel (2005) «Modernization, Cultural Change, and Democracy: The Human Development Sequence» are the basis for the study of the values dynamics. Thus, the authors demonstrated how economic development stimulated the movement from society of traditional values to secular-rational ones and from the values of survival to the values of self-expression. For political science, it is important to conclude about the impact of this cultural dynamics on the formation and functioning of a democratic system. In modern societies there are changes in both value system and institutional structure. In the value system there is a shift from "materialist" values (physical and economic security is a priority) to "postmaterialist" ones (well-being, quality of life and individual self-expression). In the institutional structure there is a shift from hierarchical bureaucratic organizations that lose functional efficiency to new structures. At the same time, the importance of the latter will continue to decline, which will correspond to the general trend - the decline of the authority of political, economic and scientific powers. Political power changes structurally from a clear hierarchical or decentralized to a network.

\section{POLITICAL MANIPULATION OF THE VALUE COMPONENT AT THE TRADITIONAL STAGE}

Security is one of the priority values of traditional society, the values of survival are of paramount importance (the need for self-realization is actualized at later stages of development). At this stage, manipulation is not the main form of government, but as a component of the functional subsystem of the political system, focuses on maintaining socio-political stability and establishing mutual agreement on the prevailing value system. Value models can determine political behavior and be influenced, including manipulative technics. And characteristics of the society of the primordial tradition (focus on the present, lack of broad freedoms, prevalence 
of patronage relations, etc.) only contribute to the spread of manipulative influences. Political traditions are the most stable elements of political culture. Values as components of tradition are slowly changing. In addition, the myth remains an effective tool for political manipulation in modern society. At the same time, manipulative methods do not play a significant functional role at the traditional stage of development. Manipulation is focused on maintaining socio-political stability and establishing mutual agreement on the prevailing value system. It is possible to actualize the values of «security» and «stability» in the public consciousness by influencing its emotional component. The appeal to the values of «survival» in manipulation influences the political behavior of the audience in the desired direction for the manipulators. The focus of political manipulation is on such topics as patriotism, heroism, self-sacrifice, which at the modern stage become elements of a legal (or legitimate) worldview and appropriate forms of political behavior, with a strong positive focus on the dominant political system.

\section{POLITICAL MANIPULATION OF THE VALUE COMPONENT OF CONSCIOUSNESS AT THE MODERN STAGE}

Freedom becomes the greatest value of modern society. The Modernism as Western European paradigm of Modern Times became an alternative concept to traditional society. As alternatives, rationalism and individualism replace faith and collectivity. Values can be transformed through mechanisms of management and manipulation (gradually as a result of evolutionary socio-political development or quickly, as a result of radical social transformations). At the modern stage, freedom became a basic value. Freedom is the cause and consequence of the further genesis of the principles of political power. Expansion of political and economic freedoms, democratization changed the forms of government. The mass character of the society and the role of the media in the twentieth century turned manipulation into a dominant form of management of human consciousness and behavior. At the same time, at the stage of modern coercion remains a tool of control (especially political behavior). 
Manipulation is aimed at controlling the political consciousness and its worldview and value structures. If at the previous stage control (albeit on a small scale) was carried out mainly through the emotional sphere, at the modern stage the cognitive component was added. Critical rationality is an obstacle to manipulation for political purposes, nevertheless, it contains mechanisms that facilitate control and management of a man.

Thus, from the point of view of historical retrospective, political manipulation of public consciousness changes its forms and scales, and hence qualitative and quantitative features, adapting to changes in sociopolitical life and value systems. The two stages of socio-political development, traditional and modern ones, differ in the priority of «survival values» or «values of self-expression» (Inglehart, 2011). The value system of traditional society changes its meaning to a more liberal, individual, rational and private, transforming political structures and state institutions. Liberalism was the quintessence of modernism; freedom became a priority. With the expansion of freedom, including political, manipulative technologies spread to ensure loyal, conformist political behavior and the appropriate state of mass consciousness. Control over the process of formation of value orientations became an important component of political management and manipulation.

Expansion of the freedom sphere, consolidation of the relevant values in the mass consciousness complicates the implementation of the authorities, which have a purely coercive, disciplinary nature. In such circumstances, there is a need to use manipulative mechanisms to restore loyalty to state power, which was desecrated as a result of democratic change. Political manipulation acquires the character of an attributive form of society governing with a decrease in the level of power legitimacy. The development of political manipulation is associated with the problem of legitimation of the state power. The crisis of legitimacy, in turn, concerns the expansion of civil rights and freedoms. In addition to freedom as a fundamental leitmotif, another element of the modern paradigm is the priority of rationality. The impact on the emotional component of social consciousness is integral to both traditional and modern stages of development. At the modern stage political manipulation uses heuristics, which are inherent in the very mechanism of thinking. Thus, from the point of 
view of historical retrospective, political manipulation of public consciousness changes its forms and scales, and hence qualitative and quantitative features, adapting to changes in socio-political life and value systems.

\section{MANIPULATION OF VALUE COMPONENT OF CONSCIOUSNESS AT THE PRESENT STAGE}

Postmodern society is experiencing a crisis of modern values. The assertion of the values of self-expression is accelerating and at the same time the secular-rational tendency, which was inherent in the previous stage, is slowing down (Zhabinets, 2002). Value systems are changing, their relativity and multiplicity are being fixed, and, accordingly, the technologies of manipulating the mass consciousness are becoming more complicated (Bauman, 2008). In postmodern, politics is perceived as a game and «the art of the possible», so the functional significance of political manipulation is only growing. Emphasis on the emotional component (post-truth) and primitivization of thinking (pseudo-thinking) are components of manipulation for political purposes at the present stage of the society development.

The politics of the contemporary stage changes its parameters in comparison with modern and traditional forms. Accordingly, both the characteristics of political governance and specific manipulation technologies change (Shmidt, 2013). The precondition for the development of manipulative practices is the genesis of political and state power in general. If coercive, disciplinary methods of authoritarian influence on political consciousness and behavior prevail, manipulation does not become widespread and fundamental. Today, the leading form of socio-political governance is political manipulation. I suppose that the organized, systematic and hidden influence on the mass and individual consciousness and behavior has become an integral part of the mechanism of regulating the political life of the contemporary society. Nowadays, manipulation is used to one degree or another in all political technologies, and increasingly - as a single and main component. The latent nature of the influence could be 
defined as decisive. In Ukraine can be distinguished such features as: control of oligarchic ruling groups over information flows, constant use of state and administrative resources, as well as methods of political manipulation.

\section{CONCLUSIONS}

Thus, the spread of emancipation in the political sphere and the expansion of the list of rights and freedoms, complicate the mass use of manipulative technologies in politics. On the other hand, the variability of political values and meanings in postmodern era could contribute to the further formal improvement of these technologies. It is obvious that the policy of manipulation changes at each stage of development: traditional, modern and postmodern. Today, the leading form of socio-political governance is political manipulation. Systematic and latent influence on mass and individual consciousness and behavior has become an integral part of the mechanism of regulating the political life of the contemporary society.

\section{BIBLIOGRAPHY:}

Adzhemohlu, D., Robinson, D. (2020). Vuzkyi korydor. Derzhavy, suspilstva i dolia svobody [Narrow corridor. States, societies and the fate of freedom]. Kyiv: Nash format [in Ukrainian].

Bauman, Z. (2008). Hlobalizatsiia. Naslidky dlia liudyny i suspilstva [Globalization. Implications for man and society]. Kyiv: Vydavnychyi dim «Kyievo-Mohylianska akademiia» [in Ukrainian].

Coons, C., Weber, M. (ed). (2014). Manipulation: Theory and Practice. N.Y: Oxford University Press.

Inglehart, R., Welzel, Ch. (2005). Modernization, Cultural Change, and Democracy: The Human Development Sequence. Cambridge: Cambridge University Press.

Inglehart, R. (2011). Izmenenie cennostej i ustojchivost kulturnyh tradicij [Change of values and stability of cultural traditions]. In Inglehart R. (ed)., Modernizaciya, kul- 
turnye izmeneniya i demokratiya: Posledovatelnost chelovecheskogo razvitiya (pp. 79-119). Moscow: Novoe izdatelstvo.

Kahneman, D. (2017). Myslennia shvydke ta povilne [Thinking fast and slow]. Kyiv: Nash format [in Ukrainian].

Levitin, D. (2017). Putevoditel po lzhi. Kriticheskoe myshlenie v epohu postpravdy [A guide to lies. Critical thinking in the post-truth era]. Moscow: Mann, Ivanov i Ferber [in Russian].

Maklyuen, M. (2014) Ponimanie media [Understanding the media]. Moscow: Novoe literaturnoe obozrenie [in Russian].

Moroz, O. (2020). Natsiia Ovochiv? Yak informatsiia zminiuie myslennia ta povedinku ukraintsiv [The Nation of Vegetables? How information changes the thinking and behavior of Ukrainians]. Kyiv: Yakaboo publishing [in Ukrainian].

Nyst, C. (ed). (2018). State-sponsored Trolling. How Governments Are Deploying Disinformation as Part of Broader Digital Harassment Campaigns. Palo Alto: Institute for the Future.

Pomerantsev, P. (2020). Tse ne propahanda [This is not propaganda]. Kyiv: Yakaboo publishing [in Ukrainian].

Shmidt, E. (2013). Novyj cifrovoj mir. Kak tehnologii menyayut zhizn lyudej, modeli biznesa i ponyatie gosudarstv [New digital world. How technology is changing people's lives, business models and the concept of states]. Moscow: MIF [In Russian].

World Values Survey. (2020). Retrieved from: http://www.worldvaluessurvey.org/wvs.jsp Zhabinets, N. (2002). Postmodernistski tsinnosti suchasnoi tsyvilizatsii [Postmodernist values of the contemporary civilization]. Humanitarnyi visnyk Zaporizkoi derzhavnoi inzhenernoi akademii. no. 11, pp. 98-101. 